Images in...

\title{
Giant cystic lung disease with mediastinal compression in a short-term heavy cannabis smoker
}

\author{
Albert Stuart Reece ${ }^{1-3}$ \\ ${ }^{1}$ School of Psychiatry and Clinical Neurosciences, University of Western Australia, Brisbane, Queensland, Australia; \\ ${ }^{2}$ Southcity Family Medical Centre, University of Queensland, Brisbane, Queensland, Australia; \\ ${ }^{3}$ Department of Medical School, University of Queensland, Brisbane, Queensland, Australia
}

Correspondence to Albert Stuart Reece, sreece@bigpond.net.au

\section{DESCRIPTION}

This case was a 44-year-old lady who had smoked cannabis heavily for 3 years from age 41-44. Her situation was unusual for two reasons. She had been advised to smoke cannabis for some migraines she had experienced, by her previous local doctor. Other prophylactic treatments had not been tried. Second, she had unlimited access to cannabis supply smoking up to $5 \mathrm{~g}$ (50 cones) daily via a bong. She had 6 months of increasing breathlessness and was no longer able to walk across a room. Her previous asthma had different symptomatology.
This case is important for several reasons. First, while cystic lung disease is a suspected complication of heavy cannabis smoking, relatively few cases have been described of this manner (figure 1). ${ }^{1-4}$ Smoking cannabis via a bong with the breath-holding increases intrathoracic pressure and promotes cyst formation. Second, long-term cannabis is known to increase cough, sputum production and airway inflammation ${ }^{2-35}$ which itself increases airway resistance exacerbating cyst formation and coalescence. This highlights the importance of tight asthma control. Third, at $19 \mathrm{~cm}$ diameter, this is the largest cyst described. Fourth,

\section{Coronal Chest C.T. Sections}
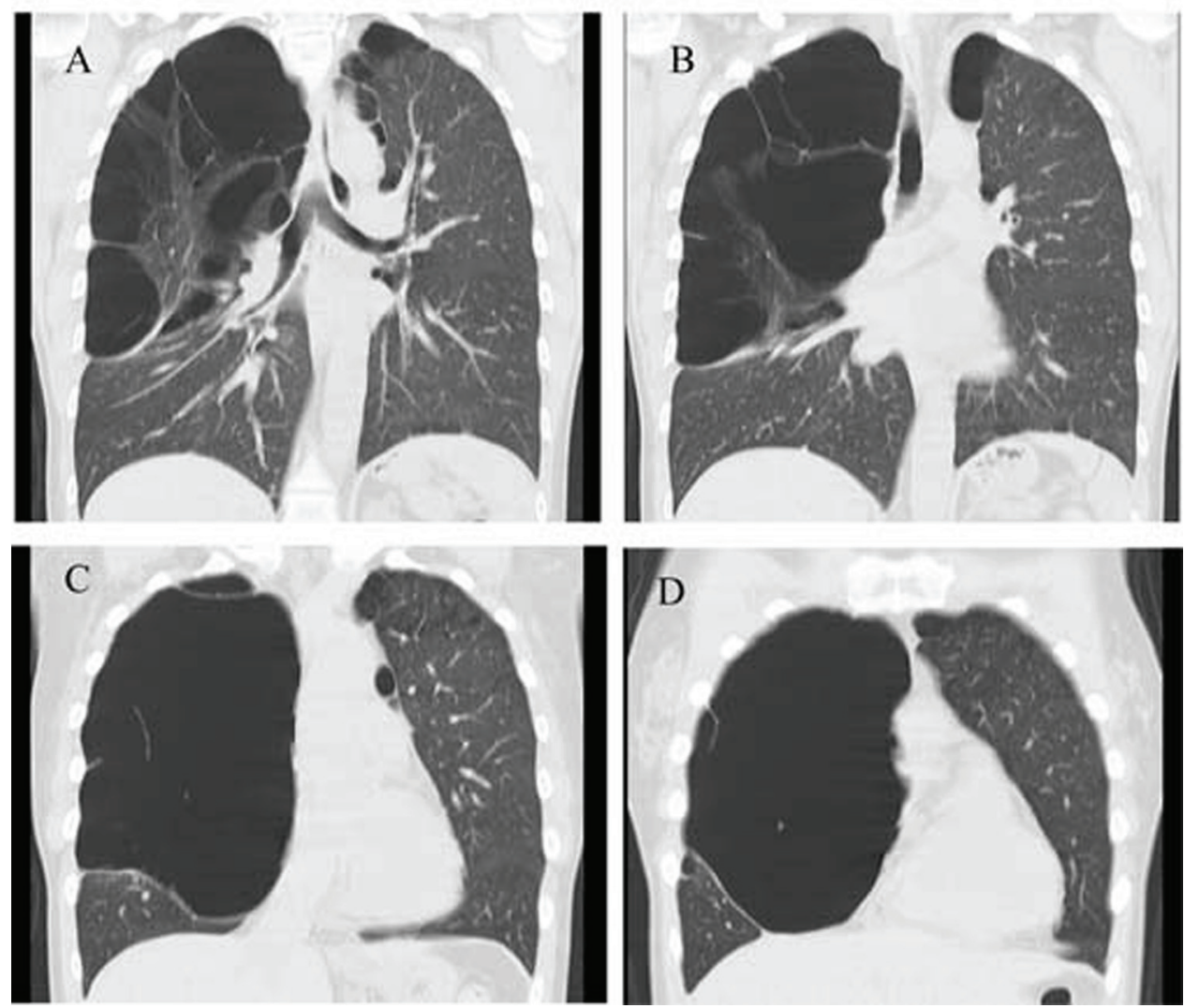

Figure 1 Coronal chest CT sections. (A) Smaller cycts posteriorly (B) Larger cysts in mid-lateral plane (C) Apparent cyst coalescence (D) Giant cyst diameter $19 \mathrm{~cm}$. 


\section{BMJ Case Reports}

there is obviously pressure in this cystic system which is responsible for compressing the remaining lung, mediastinum and contralateral lung. The disease is progressive as larger cysts grow due to their high wall tension. Fifth, the complete cessation of tobacco and cannabis consumption is clearly paramount to prevent disease progression. Sixth, such images are consistent with the increasingly recognised role of cannabis in contributing to chronic airway inflammatory change. Finally and importantly from management point of view, the localised position of the cysts concentrated almost entirely within the upper right lobe suggests that there is an important place in this patient for segmental resection and lung reduction surgery.
Competing interests None.

Patient consent Obtained.

\section{REFERENCES}

1. Reece AS. Cannabis as a cause of giant cystic lung disease. OJM 2008; 101:503

2. British Lung Foundation. Cannabis: a Smoking Gun. London: British Lung Foundation, 2005.

3. Tashkin DP. Smoked marijuana as a cause of lung injury. Monaldi Arch Chest Dis 2005:63:93-100.

4. Johnson MK, Smith RP, Morrison D, et al. Large lung bullae in marijuana smokers. Thorax 2000;55:340-2.

5. Tashkin DP. Airway effects of marijuana, cocaine, and other inhaled illicit agents. Curr Opin Pulm Med 2001;7:43-61.

This pdf has been created automatically from the final edited text and images.

Copyright 2011 BMJ Publishing Group. All rights reserved. For permission to reuse any of this content visit

http://group.bmi.com/group/rights-licensing/permissions.

BMJ Case Report Fellows may re-use this article for personal use and teaching without any further permission.

Please cite this article as follows (you will need to access the article online to obtain the date of publication).

Reece AS. Giant cystic lung disease with mediastinal compression in a short-term heavy cannabis smoker. BMJ Case Reports 2011;10.1136/bcr.04.2010.2934, date of publication

Become a Fellow of BMJ Case Reports today and you can:

- Submit as many cases as you like

- Enjoy fast sympathetic peer review and rapid publication of accepted articles

- Access all the published articles

- Re-use any of the published material for personal use and teaching without further permission

For information on Institutional Fellowships contact consortiasales@bmigroup.com

Visit casereports.bmj.com for more articles like this and to become a Fellow 